Article

\title{
The Nexus of FDI, R\&D, and Human Capital on Chinese Sustainable Development: Evidence from a Two-Step Approach
}

\author{
Sang-Do Park \\ Department of International Business Management, Woosong University, 171, Dongdaejeon-ro, Dong-gu, \\ Daejeon 34606, Korea; psd9576@naver.com; Tel.: +82-42-630-9326; Fax: +82-629-6649
}

Received: 17 April 2018; Accepted: 4 June 2018; Published: 18 June 2018

\begin{abstract}
This study examines the effect of the foreign direct investment (FDI)-human capital and R\&D-human capital interactions (FDIHC and RDHHC) on Chinese development between 1991 and 2015. Based on endogenous growth theory, the study focuses on FDI, R\&D, and human capital as important factors for sustained economic growth; the interactions among factors are set as the main variables affecting economic growth (GDP). In particular, this study attempts a two-step empirical analysis. First, data mining and semantic network analysis (SNA) are performed using variables as keywords; reliability and realism are reflected as variables. Second, using the vector error correction model (VECM), the study analyzes short and long run mutual influences between variables. The results show that, in data mining and SNA with FDI and R\&D as keywords, words related to human capital show high frequency, centrality, and clustering. This finding implies that FDIHC and RDHHC have robustness as variables and can be used as interaction variables. According to the VECM results, FDIHC and RDHHC have positive influences on GDP in the short and long run. The results of a variance decomposition test show that RDHHC has strong mid- to long-run impacts on GDP, FDIHC, and R\&D itself.
\end{abstract}

Keywords: FDI-human capital; R\&D-human capital; vector error correction model; text mining; semantic network analysis; Chinese economic growth

\section{Introduction}

A country can realize change and development through sustainable investment, and many countries have focused on foreign direct investment (FDI) and R\&D for social advancement [1]. FDI isusually considered to be the most effective means of early-stage national economic development, whereas $R \& D$ investment is recognized as an indispensable factor for sustainable development in host countries [2]. FDI can play a positive role in a host country's economic development by transferring the beneficial capital, advanced technology, management know-how, and intangible assets of an enterprise [3,4]. R\&D, as an essential factor in enhancing national competitiveness and sustainable development, emphasizes intangible assets and soft power in the process of economic development [5-9]. Thus, sustainable development places importance on the dynamics of FDI, R\&D, and soft power, such as human capital. In particular, human capital is a fundamental element of endogenous growth theory. It is categorized as a crucial factor that affects national development along with growth promotion factors like FDI and R\&D. Furthermore, human capital can play a key role in maintaining a nation's sustainable development in combination with other growth drivers. The interaction between FDI and human capital therefore entails not only pure capital inflow but also the human capital quality of the host country to which advanced knowledge and technology are introduced for acceptance [10]. In the context of $R \& D$, human capital leads to creative and 
developmental outcomes from the use of new knowledge and technology. In other words, research on national sustainable development should reveal the impact of each factor (FDI or R\&D) on growth, as well as the impacts of interactions with other factors on growth. As a result, in-depth research on the sustainable growth of a country needs to take into account both causal and interrelated dimensions.

For this analysis, I designate China as the country that can most effectively demonstrate the theoretical context of this development theory. China is the second largest economy in the world to absorb FDI after the US, and it is the largest destination for FDI among developing countries [11]. In China, FDI has brought not only the capital but also the high-level intangible assets of advanced countries, such as, for example, advanced technology, marketing know-how, distribution management, organizational management, customer management, and so on [3,4,12]. As a result, in addition to contributing to domestic capital formation, the creation of employment, and economic growth, FDI can also generate human capital growth and R\&D investment for domestic firms [13]. These two factors, shaped by FDI, have been synergizing Chinese development through continuous interactions between FDI, R\&D, and human capital. Despite the fact that the correlations and interactions between these factors have substantial impacts on China's development, many researchers to date have also focused on the independent impacts of FDI, R\&D, and human resources on Chinese economic growth [14-21]. To overcome this limitation, I explore how the interaction effects of FDI-human capital and R\&D-human capital-factors that are critical for sustainable development in developing countries-have affected Chinese economic growth.

Unlike other similar studies, this study is unique in the following ways. First, I diversify variables based on literature reviews, and I use mutual influence variables instead of simple variables such as FDI-human capital and R\&D-human capital interaction variables. Second, I examine how the FDI-human capital and R\&D-human capital interactions are publicized in China's development process. I do so because, if words are simultaneously publicized, they should be considered as influence factors based on their correlations and interactions rather than as single influence factors. For this investigation, I conduct text mining analysis and degree centrality analysis using "FDI" and "R\&D" as keywords. Third, on the methodological level, I employ two steps: the semantic network analysis (SNA) and vector error correction model (VECM) approaches. The former explores the possibility of interrelationships among three factors (FDI, R\&D, and human capital) affecting China's economic development. I choose this method because it is predictable that the interactions of the variables can occur together on the basis of the network and clusters among the three factors. The latter is an empirical, analytical process that confirms whether the three mentioned factors can independently interact to form a causal relationship in the long or short run. The combination of the two methodologies not only improves the robustness of the research analysis and empirical models but also provides thoughtful insights to explain the effects between independent and dependent variables.

The paper is structured as follows. The following section theoretically explains the impact of FDI-R\&D-human capital linkages on China's economic growth based on previous research. Section 3 sets up the two-step approach model-SNA and VECM. Data, methodology, and analysis results are presented for each step. Section 4 discusses the two-step analysis results along with policy implications. The conclusion and limitations are given in Section 5.

\section{Literature Review}

The theory of endogenous growth was developed by Romer [22] and Lucas [23]. It seeks to find factors that cause sustained economic growth in empirical models. R\&D investment, global trade, and human capital are factors that make sustainable growth possible; they emphasize the spillover effect and learning through knowledge. In particular, FDI in developing countries stimulates a number of growth factors as driving forces for economic development. Therefore, under endogenous growth theory, FDI is an essential potential component of economic growth that increases the marginal productivity of the capital stock of host countries. However, the utilization of FDI's potential requires an economic environment of active FDI inducement policy in these countries (in this respect, the 
utilization of human capital and increased investment in infrastructure are important incentives to attract FDI). Economic growth may be adversely affected if such an economic environment is not established. In this case, the private investment rate by foreign capital can be increased, but it may not have a major influence on the increase in the social returns of host countries. This result follows because, in a distorted economic environment, the mere transfer of human capital and technology through FDI is not sufficient to raise the economic levels of such countries. Therefore, FDI, especially in developing countries, can interact with the human capital of host countries and, thus, affect economic growth.

A number of empirical studies investigate the effects of FDI on economic growth. These studies can be divided into those that argue for positive [10,24-27] and negative [28-33] effects. In particular, studies that claim negative effects explain that FDI induces a crowd-out effect, because it hinders the development of local economies [29]. From a balanced standpoint, the positive effect is said to exist only if a host country sets an appropriate regulatory policy on FDI and experiences political, economic, and social stability. Furthermore, some studies do consider FDI and human capital together. For example, Borensztein et al. [10] analyzed the effects of FDI and interaction (FDI*Schooling) variables on economic growth through a regression model. They proved that the interaction variables had significant positive results. A panel analysis of developing countries by Lipsey [34] showed that the interaction effect between FDI and education level in the previous period ( $t-1)$ had a crucial impact on economic growth. Zhang [35], in a study of eleven developing countries in East Asia and South America, demonstrated that FDI, trade liberalization, export orientation, and human capital have important effects on economic growth. Durham [36] reported that FDI differs depending on the absorption capacity of a host country. He argued that education and openness in developed countries led to greater FDI benefits. Similarly, $\mathrm{Li}$ and Liu [37] found that FDI had a positive impact on both developed and developing countries and that, in developing countries, human capital and FDI interacted with each other and had a significant positive influence on economic growth.

Regarding research on the relationship between $R \& D$ and national development, there is no question that innovation through R\&D drives economic growth and enhances national competitiveness. According to the theory of economic growth, growth that depends only on the inputs of production factors, such as labor and capital, is limited; hence, innovation through R\&D is essential for sustainability. Therefore, many countries around the world have been actively expanding their R\&D investments in order to achieve sustainable growth and raise people's standards of living. In particular, $R \& D$ 's importance has further intensified with the debate on the fourth industrial revolution.

$R \& D$ promotes the growth of knowledge capital, such as research papers and patents. Knowledge capital, in turn, influences the entire national economy through imitation and diffusion. Importantly, in this context, R\&D interacts with human capital and generates new knowledge based on existing accumulated knowledge-economic growth is based on this knowledge. However, the existing literature on the nexus of $R \& D$ and national development has mostly analyzed the contribution of $R \& D$ investment to economic growth through its effect on productivity [38-43]. In other words, these studies have shown that R\&D investment contributes to economic growth by enhancing the productivity of industry and the whole country, increasing capital, which, in turn, affects economic growth.

Lichtenberg [42] suggested that private R\&D investment has a positive effect on the level and growth rate of labor productivity - that the elasticity of private R\&D stock to GNP is about one third of physical capital; that is, approximately 7\%. Goel and Ram [39] analyzed the effects of R\&D investment and intensity on the economic growth of 18 developed and 34 developing countries according to World Bank standards. The results show that, although R\&D has a statistically positive impact, its significance is not high. Furthermore, Coe and Helpman [38] analyzed the relationship between domestic and foreign R\&D investment and total factor productivity in 22 OECD countries. They found that the seven major developed countries (G7) have higher productivity gains, elasticity, and accumulation of R\&D capital. In particular, a greater pursuit of open international trade has resulted in a greater positive impact of foreign R\&D on domestic productivity. Guellec and Potterie [41] also measured the elasticity of R\&D investment for OECD countries. The results showed that government R\&D investment reveals 
a positive (+) value for productivity improvement. Estrada and Montero [44] analyzed the effects of R\&D investment on long-term economic growth in seven countries (USA, Germany, Japan, UK, France, Italy, and Spain) from 1970 to 2006. In this study, although R\&D investment had a positive effect on economic growth, government $R \& D$ sparked crowd-out effects and weakened private $R \& D$ investment.

However, rapid economic growth requires absorptive capacity and human capital to incorporate advanced technologies. Howitt and Mayer-Faulkers [45] and Dowrick and Rogers [46] emphasized the importance of human capital and technical education. Guellec and Potterie [41] found that active domestic R\&D activities led to the diffusion of knowledge in human capital and the effective transfer of technology through it. In a relatively recent study, human capital variables have added to the understanding of the impact of R\&D on growth. Bronzini and Piselli [47] empirically analyzed the long run equilibrium relationship between productivity, human capital, and R\&D in Italy. They showed that regional infrastructure investment and R\&D activities have positive effects on the productivity of a region. In particular, they explained that human capital has the greatest influence on a region's productivity improvement. Teixeira and Fortuna [48] reported the effect of efforts to emulate various advanced countries (human capital investment, R\&D investment, and trade activities) on Portugal's long-term growth. The results showed that human capital, R\&D activities, and trade all had positive impacts on long-term growth and particularly emphasized the importance of human capital investment over R\&D investment. Bengoa et al. [49] assessed the TFP-R\&D-human capital-social capital nexus across Spain for the period from 1980 to 2007. A panel cointegration analysis showed that public R\&D had a positive impact on growth, whereas no statistically significant effect was found for private R\&D. In addition, both human capital and social capital had significant impacts on TFP in the long run. Lopez-Rodriguez and Martinez-Lopez [50] tested hypotheses in 25 European countries, emphasizing that non-R\&D activities (human capital, innovation intensity), as well as R\&D innovation activities, are important factors for growth. The results showed that not just R\&D activities but also non-R\&D activities (especially human capital) served as major drivers of positive impacts on TFP. The brief results of literature reviews in this study are summarized in Table 1.

In sum, the impacts of FDI and R\&D on economic growth can themselves explain economic growth. However, given the increasing importance of knowledge capital, FDI and R\&D should be taken into account with human capital variables. Furthermore, the interactions between variables should also be analyzed to identify their impacts on economic growth. 
Table 1. A summary of studies that explore how FDI/R\&D inflows affect economic growth.

\begin{tabular}{|c|c|c|c|c|c|}
\hline \multirow{2}{*}{ Study } & \multirow{2}{*}{ Sample } & \multirow{2}{*}{ Methodology } & \multicolumn{2}{|l|}{ Variables } & \multirow{2}{*}{ Major Findings } \\
\hline & & & Dependent Variable & Major Independent Variables & \\
\hline Borensztein [10] & 69 countries (1970-1989) & SLS (Panel) & E (Economic growth) & FDI, HC (Human capital) & $\mathrm{FDI}^{*} \mathrm{HC} \rightarrow \mathrm{E}(+)$ \\
\hline $\begin{array}{l}\text { Beugelsdijk and } \\
\text { Zwinkels [24] }\end{array}$ & 44 countries (1983-2003) & GMM (Panel) & E & HFDI (horizontal FDI), VFDI (vertical FDI) & $\mathrm{HFDI} \rightarrow \mathrm{E}(+)$; VFDI $\rightarrow \mathrm{E}(+)$ in developed countries \\
\hline $\begin{array}{l}\text { Baharumshah and } \\
\text { Thanoon [25] }\end{array}$ & $\begin{array}{l}8 \text { East Asian countries } \\
(1982-2001)\end{array}$ & DGLS (Panel) & E & $\begin{array}{l}\text { FDI, SAV (gross domestic saving), LD } \\
\text { (long-term debt) }\end{array}$ & $\mathrm{FDI} \rightarrow \mathrm{E}(+) ; \mathrm{SAV} \rightarrow \mathrm{E}(+) ; \mathrm{LD} \rightarrow \mathrm{E}(+)$ \\
\hline Bwalya [26] & Zambia (1993-1995) & GMM (Panel) & E (Local firms) & HFDI, VFDI, RFDI (regional FDI) & $\mathrm{HFDI} \rightarrow \mathrm{E}(-) ; \mathrm{VFDI} \rightarrow \mathrm{E}(+) ; \mathrm{RFDI} \rightarrow \mathrm{E}(+)$ \\
\hline Javorcik [27] & $\begin{array}{l}\text { CEEC } 10 \text { countries } \\
(1993-2000)\end{array}$ & OLS (Panel) & E & HFDI, VFDI & $\mathrm{VFDI} \rightarrow \mathrm{E}(+)$ \\
\hline Agosin and Machado [28] & 3 region (1970-1996) & FEM (Panel) & I (Investment-GDP ratio) & FDI & $\begin{array}{l}\text { FDI } \rightarrow \text { I (+) in Asia; FDI } \rightarrow \text { I (+) in Africa; FDI } \rightarrow \text { I (-) } \\
\text { in Latin America }\end{array}$ \\
\hline Fry [29] & $\begin{array}{l}16 \text { developing countries } \\
(1966-1988)\end{array}$ & OLS (Panel) & E & FDI, SAV & $\mathrm{FDI} \rightarrow \mathrm{SAV}(-) ; \mathrm{FDI} \rightarrow \mathrm{E}(-)$ \\
\hline De Mello [30] & 33 countries (1980-1994) & $\begin{array}{l}\text { VAR (Time series)FEM } \\
\text { (Panel) }\end{array}$ & E & FDI & $\begin{array}{l}\text { FDI } \rightarrow \mathrm{E}(+) \text { in } 16 \text { countries from OECD;FDI } \rightarrow \mathrm{E}(-) \\
\text { in } 17 \text { countries from non-OECD }\end{array}$ \\
\hline Mencinger [31] & $\begin{array}{l}8 \text { transition countries } \\
(1994-2001)\end{array}$ & $\begin{array}{l}\text { Granger causality test } \\
\text { (Panel) }\end{array}$ & E & FDI & $\mathrm{FDI} \rightarrow \mathrm{E}(-)$ \\
\hline Zhang [35] & $\begin{array}{l}11 \text { countries in East Asia } \\
\text { and Latin America } \\
(1960-1997)\end{array}$ & ECM (Panel) & E & FDI & $\begin{array}{l}\text { FDI } \rightarrow \mathrm{E}(+) \text { in Singapore, Mexico, Hong Kong, } \\
\text { Indonesia, and Taiwan }\end{array}$ \\
\hline Ashraf et al. [32] & 123 countries (2003-2011) & GMM (Panel) & $\begin{array}{l}\text { TFP (total factor } \\
\text { productivity) }\end{array}$ & FDI & FDI has no statistically significant effect on TFP \\
\hline Durham [36] & 80 countries (1979-1998) & OLS (Panel) & $\mathrm{E}$ (GDP) & FDI, EUD (education), O (trade openness) & $\mathrm{FDI}^{*} \mathrm{O} \rightarrow \mathrm{E}(+) ; \mathrm{EUD} \rightarrow \mathrm{E}(+)$ in developed countries \\
\hline Li and Liu [37] & 84 countries (1970-1999) & SLS (Panel) & E & FDI, HC & $\mathrm{FDI} \rightarrow \mathrm{E}(+) ; \mathrm{FDI}^{*} \mathrm{HC} \rightarrow \mathrm{E}(+)$ in developing countries \\
\hline Coe and Helpman [38] & 22 countries (1971-1990) & OLS (Panel) & TFP & $\begin{array}{l}\text { DR\&D (domestic R\&D), FR\&D (foreign } \\
\text { R\&D) }\end{array}$ & FR\&D $\rightarrow$ TFP $(+)$ \\
\hline Griffith et al. [40] & 12 countries (1971-1990) & ECM (Panel) & TFP & $\mathrm{R} \& \mathrm{D}, \mathrm{HC})$ & $\mathrm{R} \& \mathrm{D} \rightarrow \mathrm{TFP}(+) ; \mathrm{HC} \rightarrow \operatorname{TFP}(+)$ \\
\hline Guellec and Potterie [41] & $\begin{array}{l}\text { 16 OECD countries } \\
(1980-1998)\end{array}$ & ECM (Panel) & $\begin{array}{l}\text { MFP } \\
\text { (multi-factorproductivity) }\end{array}$ & $\begin{array}{l}\text { R\&D (included type of business, foreign, } \\
\text { public, government, and university) }\end{array}$ & $\mathrm{R} \& \mathrm{D} \rightarrow \mathrm{MFP}(+)$ \\
\hline Lichtenberg [42] & 74 countries (1964-1989) & NLSM (Panel) & LP (labor productivity) & $R \& D$ (private funded) & $\mathrm{R} \& \mathrm{D} \rightarrow \mathrm{LP}(+)$ \\
\hline $\begin{array}{l}\text { Lichtenberg and } \\
\text { Potterie [43] }\end{array}$ & 22 countries (1971-1990) & OLS (Panel) & TFP & FR\&D, O & $\mathrm{FR} \& \mathrm{D} \rightarrow \mathrm{TFP}(+) ; \mathrm{O} \rightarrow \mathrm{TFP}(+)$ \\
\hline Estrada and Montero [44] & 7 countries (1970-2006) & SVAR (Panel) & $\mathrm{E}$ (GDP) & R\&D (included government and private) & $\mathrm{R} \& \mathrm{D} \rightarrow \mathrm{E}(+)$ \\
\hline Dowrick and Rogers [46] & 57 countries $(1965-1990)$ & OLS, GMM(Panel) & E (heterogeneous growth) & R\&D, EDU (education) & $\mathrm{R} \& \mathrm{D} \rightarrow \mathrm{E}(+) ; \mathrm{EDU} \rightarrow \mathrm{E}(+)$ \\
\hline
\end{tabular}


Table 1. Cont

\begin{tabular}{|c|c|c|c|c|c|}
\hline \multirow{2}{*}{ Study } & \multirow{2}{*}{ Sample } & \multirow{2}{*}{ Methodology } & \multicolumn{2}{|l|}{ Variables } & \multirow{2}{*}{ Major Findings } \\
\hline & & & Dependent Variable & Major Independent Variables & \\
\hline Bronzini and Piselli [47] & $\begin{array}{l}19 \text { region in Italy } \\
(1980-2001)\end{array}$ & FLMOS (Panel) & TFP & R\&D, HC, ISI (infra structure investment) & $\mathrm{R} \& \mathrm{D} \rightarrow \mathrm{TFP}(+) ; \mathrm{HC} \rightarrow \mathrm{TFP}(+) ; \mathrm{ISI} \rightarrow \mathrm{TFP}(+)$ \\
\hline Teixeira and Fortuna [48] & Portugal (1960-2001) & VAR (Time series) & TFP & R\&D, HC, T (trade) & $\mathrm{R} \& \mathrm{D} \rightarrow \mathrm{TFP}(+) ; \mathrm{HC} \rightarrow \operatorname{TFP}(+) ; \mathrm{T} \rightarrow \mathrm{TFP}(+)$ \\
\hline Bengoa et al. [49] & $\begin{array}{l}17 \text { region in Spanish } \\
(1980-2007)\end{array}$ & DOLS (Panel) & TFP & R\&D (public, private), $\mathrm{P}$ (patents), $\mathrm{HC}$ & $\mathrm{R} \& \mathrm{D}($ public $) \rightarrow \operatorname{TFP}(+) ; \mathrm{P} \rightarrow \mathrm{TRP}(+) ; \mathrm{HC} \rightarrow \operatorname{TFP}(+)$ \\
\hline $\begin{array}{l}\text { Lopez-Rodriguez and } \\
\text { Martinez-Lopez [50] }\end{array}$ & $\begin{array}{l}25 \text { countries in EU } \\
(2004-2008)\end{array}$ & OLS (Panel) & TFP & R\&D, Non R\&D (HC) & $\mathrm{R} \& \mathrm{D} \rightarrow \mathrm{TFP}(+) ; \mathrm{HC} \rightarrow \operatorname{TFP}(+)$ \\
\hline
\end{tabular}

Notes: SLS = stage least squares, GMM = generalized method of moments, DGLS = dynamic generalized least squares, CEECs $=$ central and eastern European countries, OLS = ordinary least squares, FEM = fixed effect model, VAR = vector autoregression, ECM = error correction model, NLSM = nonlinear least squares method, SVAR = structural vector autoregressive, FMOLS = fully modified ordinary least squares, $\mathrm{E}=$ economic growth (or GDP), I = investment GDP ratio, TFP = total factor productivity, MFP = multi-factor productivity, LP = labor FMOLS $=$ fully modified ordinary least squares, $\mathrm{E}=$ economic growth $($ or $\mathrm{GDP}), \mathrm{I}=$ investment GDP ratio, $\mathrm{TFP}=$ total factor productivity, $\mathrm{MFP}=$ multi-factor productivity, $\mathrm{LP}=$ labor
productivity, $\mathrm{FDI}=$ foreign direct investment, $\mathrm{HC}=$ human capital, $\mathrm{HFDI}=$ horizontal FDI, VFDI = vertical FDI, SAV = gross domestic saving, $\mathrm{LD}=$ long-term debt, RFDI $=$ regional FDI, $\mathrm{EDU}=$ education, $\mathrm{O}=$ trade openness, $\mathrm{DR} \& \mathrm{D}=$ domestic $R \& D, F R \& D=$ foreign $R \& D, I S I=$ infra structure investment, $\mathrm{T}=$ trade, $\mathrm{P}=$ patents, respectively. 


\section{Materials and Methods}

This study defines the role of FDI and R\&D interaction with human capital in China's economic growth through the combination of two analysis methodologies: SNA and VECM. I focus on enhancing the robustness of the research model and interpreting it from abundant and diverse perspectives by pre-verifying the interrelationships among the variables through SNA before performing empirical analysis using the VECM. In other words, by analyzing unstructured data through SNA, I examine the mutual influence, centrality, and structural similarity of the words implied by the variables. Then, I verify the interactions and roles of the variables through the final analysis of the formal data using the VECM.

\subsection{Step One: Semantic Network Analysis}

SNA is a method for analyzing big data by finding patterns that are interconnected in the nonlinear relationship of unstructured data. Specifically, the SNA method treats the words collected through the main keyword as nodes in the network, and the connection relations and patterns between the words are regarded as semantic social relations [51]. By interpreting the structural features, I can explore the contexts in which a given keyword is discussed and understood in public and expert discourses [52]. In this regard, network theorists have argued that clusters or patterns derived from the frequency, co-occurrence, and centrality of words occurring in a network can explore the meanings represented in the text $[53,54]$. This study uses word frequency to construct the text mining, as well as term frequency-inverse document frequency (TF-IDF) and degree centrality analysis. SNA is established based on a matrix after word cleaning and text mining.

\subsubsection{Data}

Through ICTCLAS [55], using the keywords of FDI and R\&D, this study gathered data for news and documents for a five-year period up to 2016 on a Chinese portal (Baidu, Beijing, China). Baidu, the leading Chinese search engine, accounts for more than $95 \%$ of the search market, making it the most appropriate channel for exploring China's discourse. In total, I picked up 5683 words ( 2326 for FDI and 3357 for R\&D) from Baidu that were then analyzed after data cleaning. For SNA, about 80 top words were extracted for each keyword based on the occurrence frequency and degree centrality values.

\subsubsection{Text Mining: TF-IDF and Degree Centrality}

This study estimates TF-IDF and degree centrality using a Python module for Chinese words. These classifications are determined by importance based on the term frequency and centrality estimation, which is based on the focus of the links between nodes (words or texts) in the semantic network [56]. In this network, a node in a geodesic path between other pairs of nodes is considered to occupy a critical location.

The TF-IDF value is useful for extracting valuable information in the process of text mining with unstructured data. This value is a measure of the importance of a particular word in a document using statistical techniques. In other words, if the frequency of a certain word is high, it can be considered important in the document, but, conversely, it can also imply that the word is a universal word. Thus, the importance of a particular word increases in proportion to the frequency of its occurrence in the document, but, in fact, the importance must be offset by the frequency of the corpus word. TF-IDF values are used by search engines to extract the information that is most relevant to user queries, and they are a key criterion for associating and ranking documents [57]. Depending on the attributes of the connection relationship, centrality can be interpreted in various ways (e.g., degree, closeness, and betweenness) [58]. Degree centricity refers to the degree of strong connection and attention in the network, which can be useful as the simplest and most effective indicator of the power relationship across nodes $[59,60]$. Degree centrality is measured to the extent to which a node is connected to 
another node in the network. Table 2 shows the results of text mining for the two main subject words (FDI and R\&D).

Table 2. The result of textmining on FDI/R\&D.

\begin{tabular}{|c|c|c|}
\hline & & Human Capital-Related Words (TF-IDF/Degree Centrality) \\
\hline \multirow{2}{*}{$\begin{array}{l}\text { Subject } \\
\text { words }\end{array}$} & FDI & $\begin{array}{l}\text { Entrepreneur (358.905/0.037), Coll. and Univ. }(331.324 / 0.075), \text { Talented Person } \\
(208.732 / 0.028), \text { Human Resource }(165.101 / 0.041), \text { Research Paper }(148.161 / 0.025), \\
\text { Knowledge }(112.765 / 0.015), \text { Investor }(111.089 / 0.016), \text { College Students }(96.755 / 0.016) \text {, } \\
\text { Junior College }(91.589 / 0.011) \text {, Income }(82.746 / 0.010) \text {, Salary }(76.482 / 0.010), \text { Doctor } \\
(73.396 / 0.010), \text { Graduate Students }(65.545 / 0.006), \text { Works }(63.293 / 0.006), \text { Bonus } \\
(56.803 / 0.006)\end{array}$ \\
\hline & R\&D & $\begin{array}{l}\text { Research Paper (301.616/0.051), University }(228.511 / 0.040), \text { Academic Degree } \\
(199.626 / 0.013), \text { Professional }(193.823 / 0.019), \text { Intelligence }(187.768 / 0.019), \text { Engineer } \\
(186.855 / 0.028), \text { Master }(184.159 / 0.010), \text { Teaching }(165.952 / 0.011), \text { Curriculum } \\
\text { (160.803/0.012), Talented Person }(147.661 / 0.017), \text { Wisdom Knowledge }(140.015 / 0.002), \\
\text { Expert (116.755/0.008), Human Resource }(109.888 / 0.013), \text { Knowledge }(109.741 / 0.012), \\
\text { Teacher }(90.704 / 0.015), \text { Academic }(87.036 / 0.008)\end{array}$ \\
\hline
\end{tabular}

Table 2 shows the results of textmining on FDI and R\&D. Specifically, the table shows which words are selected based on more than 70 words with high frequency and importance among the 5638 words that were searched, extracted, and refined for FDI and R\&D. First, in terms of the frequency and importance of terms related to FDI, words related to human capital (e.g., Entrepreneur, Coll. And Univ., Talented Person, Human Resource, Research Paper, Knowledge, Investor, College Student, Junior College, Income, Salary, Doctor, Graduate Student, Works, and Bonus) are found. This relation implies that talented people are needed for local affairs in the process of FDI inflow, or that talented people are needed to utilize FDI after its inflow. In particular, from the centrality of the words related to FDI, Coll. and Univ. (TF-IDF/degree centrality ranking; 11/5), Human Resource (31/13), Investor (50/39), and College Student $(52 / 38)$ are found to be low in frequency but highly centralized (see Appendix A Table A1). These results show that human resources, such as investors and college students, play an important role in the inflow and utilization of FDI, and that the intrinsic performance of FDI can be achieved through interactions with human resources beyond the inflow of FDI.

Second, a total of 3357 related words are collected using R\&D as the main word. The top 82 words are extracted based on frequency, importance, and centrality. As with the results of the FDI-related word analysis, words associated with human capital (e.g., Research Paper, University, Academic Degree, Professional, Intelligence, Engineer, Master, Teaching, Curriculum, Talented Person, Wisdom Knowledge, Expert, College, Human Resource, Knowledge, Teacher, and Academic) are also relatively high among the R\&D-related words. This result means that R\&D cannot be considered separately from human capital. The basic premise of R\&D goes hand in hand with the intellectual output of academics and experts. Therefore, quantitative growth, such as R\&D investment, is important, but qualitative growth that utilizes human resources appropriately is also an important factor for deriving R\&D results. The notable words are University (TF-IDF/degree centrality ranking; 20/9), Engineer (31/15), Talented People (44/36), College (61/38), Human Resource (64/50), Knowledge (65/55), and Teacher (79/44). These words appear to have relatively high centralities but low frequencies of occurrence (see Appendix $A$ Table A2). This result implies that human capital has a positive influence on R\&D. Furthermore, the availability of competent human resources is directly related to R\&D performance.

In sum, I have confirmed that human resources are closely related to FDI and R\&D. This finding raises the need to look at the interaction effects, as well as the independent effects between the three factors, and it also serves as a basis for enhancing the robustness of the interaction variables (FDIHC, RDHHC) used in this analysis. In particular, in terms of absorptive capacity, the results of text mining support the finding that an influx of FDI brings more benefits to developed countries where 
human capital is relatively developed [36,37], and that R\&D investment in human capital should precede infrastructure investment [47].

\subsubsection{Results of SNA}

Convergence of iterated correlations (CONCOR) analysis, a type of semantic network analysis, is applied in this study. First, based on extracted unstructured data related to the main subjects (FDI and R\&D), I construct a co-occurrence matrix of words $x$ words using WORDij. WORDij (http:/ / wordij.net) is a program used to analyze various types of unstructured data, as in computational linguistics, text, and content analysis, and network visualization [52]. Second, I use the CONCOR matrix (correlation or eigenvalue) to determine the similarities and patterns of relationships between the row vectors of each node [51,61]. The CONCOR analysis is performed to identify semantic clustering in the entire network surrounding the topic, to discover hidden subgroups, and to explore the relationships between the groups $[62,63]$. In this study, SNA is performed based on the correlation matrix between words. In particular, I perform CONCOR analysis to cluster words and identify the nature and properties of major clusters; the results of this analysis are shown in Table 3.

Table 3. The result of the CONCOR analysis.

\begin{tabular}{lcc}
\hline & \multicolumn{2}{c}{ Subject Word } \\
\hline Number of clusters & \multicolumn{1}{c}{ FDI } & \multicolumn{1}{c}{ R\&D } \\
\hline Average clustering coefficient & 5 & 4 \\
\hline Major hub nodes & \multicolumn{1}{c}{5.157} & 2.263 \\
\hline & $\begin{array}{l}\text { FDI, Dollar, Shandong, Entrepreneur, } \\
\text { Branch Office, Global, Coll. and Univ., } \\
\text { Talented Person }\end{array}$ & $\begin{array}{l}\text { System, Technology, Project, } \\
\text { Enterprise, New Drug, Research } \\
\text { Paper, Academic Degree, Master }\end{array}$ \\
$\begin{array}{l}\text { Significant keywords in the cluster } \\
\text { (human capital perspective) }\end{array}$ & $\begin{array}{l}\text { Entrepreneur, Coll. and Univ. A Talented } \\
\text { Person, Human Resource, Research Paper }\end{array}$ & $\begin{array}{l}\text { Research Paper, University, } \\
\text { Academic Degree, Engineer, } \\
\text { Master, Teaching, Talented Person, } \\
\text { Wisdom Knowledge, Expert, } \\
\text { Human Resource, Knowledge }\end{array}$ \\
\hline
\end{tabular}

A total of five clusters are found in SNA related to FDI. The average clustering coefficient is 5.157, which implies tightness with neighboring nodes. There are eight major hub nodes, and three hubs are associated with human capital (Entrepreneur, Coll. and Univ., and Talented Person). Furthermore, I identify two significant keywords (Human Resource and Research Paper) related to human capital in addition to the hub node in the cluster. For R\&D, four clusters are identified, and the average coefficient is 2.263. There are nine main hubs in the network and three hubs (Research Paper, Academic Degree, and Master) related to human capital. Additionally, it can be seen that 11 keywords among the words in the cluster are relatively strongly related to human capital.

Specifically, I find that words related to advanced talent (e.g., Talented Person, Knowledge, and Human Resource) play an important role in various fields where FDI is used (e.g., Finance, One Road One Belt, Fund Management, and Project Management). In other words, the results show that the role of human capital is necessary to enhance the effectiveness of FDI, which can aid host countries when various human capital factors interact with FDI (see Appendix B, Figure A1).Regarding R\&D, the main clusters contain words referring to R\&D core fields, such as Information, Software, Computer, Technology, and Machine, and words related to human capital (e.g., Professional, Expert, Academic Degree, and Master), which are bound together. In other clusters, companies are interested in utilizing human capital in production and strategic management processes through R\&D activities. Furthermore, they have been attempting to maximize $R \& D$ performance through the interaction between $R \& D$ and human capital. The results suggest that R\&D must be supported by human capital (researchers, experts, etc.) in order to have a positive impact on the economic growth of a host country. In addition, the SNA result 
that examines the contribution of economic growth to $R \& D$ and human capital interactions is more meaningful than that of simple R\&D investment to economic growth (see Appendix B, Figure A2).

\subsection{Step Two: VECM Analysis}

The advantage of a multivariable equation is that the disturbance of a particular variable can be corrected by a single variable or a combination of variables. The cointegrating vector error correction (VEC) equation is also a spin-off framework with the ability to coordinate and respond to disturbances when a different set of variables is observed within the variables [64]. Hence, based on the VECM, this study examines the relationship between interaction variables (FDI-and R\&D-human capital) and China's economic growth. In particular, I set up a comparative model consisting of FDI, R\&D, and GDP to examine the relative elasticities of the interaction variables.

\subsubsection{Data}

The data used for the verification of this study model were collected using an online data set provided by the National Bureau of Statistics of China (http:/ / data.stats.gov.cn) based on the China Statistical Yearbook, the China Labor Yearbook, the China R\&D Yearbook, and the Statistics Department of the Commerce Department of China. The data in this analysis use a time series from 1991 to 2016, wherein FDI- and R\&D-related statistics coexist. FDIHC is the interaction variable between FDI and human capital. The FDI value (FDI) indicates the total amount of foreign investment actually incurred by firms each year, and human capital (HC) represents the growth rate of new employees among college graduates each year. R\&D-human capital is the interaction variable between $R \& D$ and human capital. The R\&D value (RD) refers to the total amount invested in R\&D each year, and human capital (HHC) refers to the annual growth rate of regular workers in R\&D-related industries. All variables are converted into real values based on1991 prices and substituted into the model after taking natural logs.

\subsubsection{Methodology}

According to the Monte Carlo evidence reported by Guilkey and Salemi [65] and Geweke et al. [66], among many techniques, Granger causality tests provide the most reliable results for small sample sizes. Thus, Granger causality tests [67] based on the VAR model are applied in this study to analyze the nexus between FDI-human capital interaction, R\&D-human capital interaction, and economic growth. These tests, however, must fit the assumption that the time series variables used in the model are stable. If the time series variables are non-stationary, the data stability condition for applying the VAR model is violated, resulting in an invalid Granger causality test statistic. Granger [67] pointed out that if variables are non-stationary and cointegration exists after the first difference, then the model that is suitable for investigating the relationship between these time series variables is the VECM. Applying the main variables used in this study, the equation is expressed as follows:

$$
\begin{gathered}
\Delta G D P_{t}=c_{1}+\sum_{i=1}^{n} \alpha_{1 i} \Delta G D P_{t-i}+\sum_{j=1}^{n} \beta_{1 j} \Delta F D I H C_{t-j}+\sum_{k=1}^{n} \gamma_{1 k} \Delta R D H H C_{t-k}+\varnothing_{1} E_{T C}+\epsilon_{t-1}+\epsilon_{1 t} \\
\Delta F D I H C_{t}=c_{2}+\sum_{i=1}^{n} \alpha_{2 i} \Delta F D I H C_{t-i}+\sum_{j=1}^{n} \beta_{2 j} \Delta R D H H C_{t-j}+\sum_{k=1}^{n} \gamma_{2 k} \Delta G D P_{t-k}+\varnothing_{2} E T C_{t-1}+\epsilon_{2 t} \\
\Delta R D H H C_{t}=c_{3}+\sum_{i=1}^{n} \alpha_{2 i} \Delta R D H H C_{t-i}+\sum_{j=1}^{n} \beta_{3 j} \Delta G D P_{t-j}+\sum_{k=1}^{n} \gamma_{3 k} \Delta F D I H C_{t-k}+\varnothing_{3} E_{T C} C_{t-1}+\epsilon_{3 t}
\end{gathered}
$$

in which $\mathbf{c}, \alpha, \beta$, and $\gamma$ are coefficients of the polynomial; $n$ is the optimal lag; $\operatorname{ETC}_{t-1}$ is the correction term; and $\epsilon_{1 t}$ is the disturbance term. Equation (1) expresses the causality test model from FDIHC and RDHHC to GDP. If the null hypothesis $\left(H_{0}: \beta_{1 j}=\gamma_{1 k}=0\right)$ is rejected in Equation (1), short-run Granger causality is established from FDIHC and RDHHC to GDP. The coefficient $\left(\varnothing_{1}\right)$ of the error correction term shows the speed of adjustment towards equilibrium. As such, if the 
null hypothesis $\left(H_{0}: \varnothing_{1}=0\right)$ is rejected, long run Granger causality is established from right to left. Similarly, in the causality test model from RDHHC and GDP (or GDP and FDIHC) to FDIHC (or RDHHC), rejection of the null hypotheses $H_{0}: \beta_{2 j}=\gamma_{2 k}=\mathbf{0}$ and $\boldsymbol{H}_{0}: \varnothing_{2}=\mathbf{0}$ (or $H_{0}: \beta_{3 j}=\gamma_{3 k}=0$ and $\left.H_{0}: \varnothing_{3}=0\right)$ reflects short run Granger causality from right to left.

\subsubsection{Unit Root Test}

If the stationarity of the time series variables is not secured, a spurious regression phenomenon, which appears to be irrelevant to the regression analysis, can be found. Therefore, a unit root test is performed to determine the stability of the time series data. Key techniques of the unit root test are the augmented Dickey-Fuller (ADF) and Phillips-Perron (PP) tests. The ADF test is most widely used, as it accounts for possible serial correlation term by adding lagged dependent variables but assumes that the correction terms are free of heteroscedasticity [68]. The PP test [69] makes a non-parametric correction for serial correlation while taking into consideration both autocorrelation and heteroscedasticity. The optimal lag length is selected based on the Schwartz information criterion [70]; all kinds of cases, such as "constant," "constant with trend," and "none", are considered.

Table 4 shows the results of the ADF and PP unit root tests for the FDI, RD, HC, HHC, FDIHC, RDHHC, and GDP time series data. The results indicate that the null hypothesis (unit root exists) is not rejected at the $1 \%$ significance level, which means that the time series variable is not stable when it is a level variable. Therefore, in order to apply the variable correctly to the model, it is suggested to use strictly standard data with a higher-level variable, namely, a differential variable. However, the null hypothesis that the seven time series data are unstable is rejected at the $1 \%$ significance level after first differencing. All variables introduced in the model can be categorized as non-stationary time series data, but the first difference variables are found to be stable time series data with no unit roots.

Table 4. Results of the unit root tests.

\begin{tabular}{|c|c|c|c|c|c|c|c|}
\hline \multirow{2}{*}{ Variables } & & \multicolumn{3}{|l|}{$\mathrm{ADF}$} & \multicolumn{3}{|l|}{ PP } \\
\hline & & C & CT & None & C & CT & None \\
\hline GDP & $\begin{array}{l}\text { Level } \\
\Delta\end{array}$ & $\begin{array}{l}-1.991 \\
-6.121\end{array}$ & $\begin{array}{l}-2.761 \\
-5.958\end{array}$ & $\begin{array}{l}0.929 \\
-5.739 \text { *** }\end{array}$ & $\begin{array}{l}-0.743 \\
-9.229\end{array}$ & $\begin{array}{l}-2.695 \\
-8.947 * * *\end{array}$ & $\begin{array}{l}0.282 \\
-5.500\end{array}$ \\
\hline FDI & $\begin{array}{l}\text { Level } \\
\Delta\end{array}$ & $\begin{array}{l}-0.598 \\
-4.601\end{array}$ & $\begin{array}{l}-1.713 \\
-4.494\end{array}$ & $\begin{array}{l}2.975 \\
-3.168 * * *\end{array}$ & $\begin{array}{l}-0.598 \\
-4.597 \text { *** }\end{array}$ & $\begin{array}{l}-1.789 \\
-4.489 * * *\end{array}$ & $\begin{array}{l}2.777 \\
-3.077 \text { *** }\end{array}$ \\
\hline RD & $\begin{array}{l}\text { Level } \\
\Delta\end{array}$ & $\begin{array}{l}-0.320 \\
-3.532\end{array}$ & $\begin{array}{l}-2.727 \\
-3.865\end{array}$ & $\begin{array}{l}1.047 \\
-3.188^{* * *}\end{array}$ & $\begin{array}{l}-0.481 \\
-3.518 \\
\end{array}$ & $\begin{array}{l}-2.010 \\
-3.444\end{array}$ & $\begin{array}{l}0.683 \\
-3.235\end{array}$ \\
\hline $\mathrm{HC}$ & $\begin{array}{l}\text { Level } \\
\Delta\end{array}$ & $\begin{array}{l}-2.031 \\
-4.542\end{array}$ & $\begin{array}{l}-1.952 \\
-4.616^{\text {*** }}\end{array}$ & $\begin{array}{l}-1.002 \\
-4.654\end{array}$ & $\begin{array}{l}-1.898 \\
-3.741\end{array}$ & $\begin{array}{l}-1.820 \\
-4.546^{* * *}\end{array}$ & $\begin{array}{l}-1.422 \\
-3.877\end{array}$ \\
\hline $\mathrm{HHC}$ & $\begin{array}{l}\text { Level } \\
\Delta\end{array}$ & $\begin{array}{l}-3.011^{* *} \\
-8.347^{* * *}\end{array}$ & $\begin{array}{l}0.008 \\
-8.494^{* * *}\end{array}$ & $\begin{array}{l}-0.954 \\
-8.534\end{array}$ & $\begin{array}{l}-2.896^{*} \\
-8.956^{* * *}\end{array}$ & $\begin{array}{l}-2.944 \\
-13.392 \text { *** }\end{array}$ & $\begin{array}{l}-1.427 \\
-9.189\end{array}$ \\
\hline FDIHC & $\begin{array}{l}\text { Level } \\
\Delta\end{array}$ & $\begin{array}{l}-0.320 \\
-9.005\end{array}$ & $\begin{array}{l}-3.340 * \\
-3.712\end{array}$ & $\begin{array}{l}0.659 \\
-8.677^{* * *}\end{array}$ & $\begin{array}{l}-1.355 \\
-9.592\end{array}$ & $\begin{array}{l}-3.317^{*} \\
-9.575^{* * *}\end{array}$ & $\begin{array}{l}-0.592 \\
-8.820\end{array}$ \\
\hline RDHHC & $\begin{array}{l}\text { Level } \\
\Delta\end{array}$ & $\begin{array}{l}-3.959^{* * *} \\
-4.058^{* * *}\end{array}$ & $\begin{array}{l}-4.175^{* *} \\
-4.131^{* *}\end{array}$ & $\begin{array}{l}-3.710^{* * *} \\
-4.147^{* * *}\end{array}$ & $\begin{array}{l}-1.474 \\
-4.117^{* * *}\end{array}$ & $\begin{array}{l}-1.340 \\
-4.185^{* * *}\end{array}$ & $\begin{array}{l}-1.070 \\
-4.201\end{array}$ *** \\
\hline
\end{tabular}

Note: ADF stands for augmented Dickey-Fuller test; PP stands for Phillips Perron test; C stands for constant; CT stands for constant and trend; ***,**, and * denote significance at the $1 \%, 5 \%$, and $10 \%$ levels, respectively.

\subsubsection{Cointegration Test}

Since the unit roots are found to exist in each time series, I next determine the cointegration relation of the variables. The Johansen test, regarded as the most superior cointegration test, enables various types of hypothesis testing in addition to estimating the cointegration parameter. Thus, I use the Johansen [71] test to determine the cointegration of time series variables used in the model. As in 
the unit root test, to reduce bias and ensure accurate results, optimal lags are selected to minimize the Schwartz [70] criterion statistics.

The results of the cointegration test using the Johansen test method are shown in Table 5; both trace and maximal eigenvalue tests are applied. Both test results are able to reject the null hypothesis that no cointegration exists at the $1 \%$ significance level. The null hypothesis $\left(\mathrm{H}_{0}: \mathrm{r} \leq 1\right)$ that a maximum of one cointegration exists cannot be rejected, which indicates that one cointegration exists. Thus, there exists a long run balanced relationship between the variables of model 1 and model 2 .

Table 5. Results of the Johansen cointegration test.

\begin{tabular}{|c|c|c|c|c|c|c|c|}
\hline Models & Null Hypothesis & Trace Statistics & $5 \%$ Critical Value & Prob. & Max Eigenvalue & $5 \%$ Critical Value & Prob. \\
\hline \multirow[b]{2}{*}{ Model 1} & HO: $r=0$ & $33.141^{* *}$ & 29.797 & 0.020 & $23.236^{* *}$ & 21.132 & 0.025 \\
\hline & H0: $r \leq 1$ & 9.906 & 15.495 & 0.288 & 9.903 & 14.265 & 0.218 \\
\hline \multirow{3}{*}{ Model 2} & $\mathrm{HO}: \mathrm{r}=0$ & $47.994^{* *}$ & 29.797 & 0.000 & $38.964 * *$ & 21.132 & 0.000 \\
\hline & $\mathrm{H} 0: \mathrm{r} \leq 1$ & 9.030 & 15.495 & 0.363 & 8.255 & 14.265 & 0.353 \\
\hline & $\mathrm{H} 0: \mathrm{r} \leq 2$ & 0.775 & 3.841 & 0.379 & 0.775 & 3.841 & 0.379 \\
\hline
\end{tabular}

Note: Model 1: The cointegration between GDP, FDI, and RD; Model 2: The cointegration between GDP, FDIHC, and RDHHC; $r$ denotes the number of cointegrating vectors; optimal lag $=3$ based on SC statistics; ${ }^{* * *}, * *$, and * denote significance at the $1 \%, 5 \%$, and $10 \%$ levels, respectively.

\subsubsection{Causality Analysis Using a VECM}

In the preceding test, I find that each time series variable has a unit root and that a cointegration vector exists between the variables of model 1 and model 2.Hence, I conduct Granger causality tests [67] based on the VECM. The VECM assumes that all variables included in the model are regarded as endogenous. In order to test causality using the VECM, the appropriate time lag should be selected for the model. Since the time lag structure has a sensitive effect on the result of the causality test, if the number of time lags is arbitrarily set, it can distort the estimation factor and lead to false causal reasoning. This study uses a model with a time lag of three at the minimum SC statistic. I conduct the Granger causality test by estimating the following VECM:

$$
\left[\begin{array}{c}
\Delta G D P_{t} \\
\Delta F D I H C_{t} \\
\Delta R D H H C_{t}
\end{array}\right]=\left[\begin{array}{c}
c_{1} \\
c_{2} \\
c_{3}
\end{array}\right]+\sum_{i=1}^{n}\left[\begin{array}{ccc}
\theta_{11 i} & \theta_{12 i} & \theta_{13 i} \\
\theta_{21 i} & \theta_{22 i} & \theta_{23 i} \\
\theta_{31 i} & \theta_{32 i} & \theta_{33 i}
\end{array}\right]\left[\begin{array}{c}
\Delta G D P_{t-i} \\
\Delta F D I H C_{t-i} \\
\Delta R D H H C_{t-i}
\end{array}\right]+\left[\begin{array}{l}
\varnothing_{1} \\
\varnothing_{2} \\
\varnothing_{3}
\end{array}\right]\left[E C T_{t-1}\right]+\left[\begin{array}{c}
\epsilon_{1 t} \\
\epsilon_{2 t} \\
\epsilon_{3 t}
\end{array}\right]
$$

in which $\Delta$ represents the first difference operator. $c_{i} \mathrm{~s}$ and $\epsilon_{i t} \mathrm{~s}$ represent intercepts and error terms of each equation for $\boldsymbol{i}=\mathbf{1}, 2,3$, respectively. $E C T_{t-1}$ indicates the error correction term (in model 1, $\triangle F D I$ and $\triangle R D$ values are substituted for $\triangle F D I H C$ and $\triangle R D H H C$, respectively). In the long run, if the coefficients on the error correction terms are statistically significant using $t$-statistics, then there is a causal link from the independent variable to the dependent variable. In order to determine whether short run causality exists, the joint significance of the coefficients of each independent variable should be tested using the $F$-statistics of the Wald test. If the $F$-statistic of the explanatory variable is significant, then there is a short run causal relationship between that variable and the dependent variable [72]. In this study, I use the Granger causality test based on VECM to investigate the causal relationship between long and short run variables. The results of the causality test are shown in Table 6. 
Table 6. Results of the VECM Granger causality test.

\begin{tabular}{|c|c|c|c|c|c|c|c|c|}
\hline \multirow{3}{*}{ Models } & \multirow{3}{*}{$\begin{array}{l}\text { Dependent } \\
\text { Variables }\end{array}$} & \multicolumn{6}{|c|}{ Type of Granger Causality } & \multirow{3}{*}{ Inferences } \\
\hline & & \multicolumn{5}{|c|}{ Short Run } & \multirow{2}{*}{$\begin{array}{l}\text { Long Run } \\
\text { ETCt-1 }\end{array}$} & \\
\hline & & $\Delta \mathrm{GDP}$ & $\Delta$ FDI & $\Delta \mathrm{RD}$ & $\Delta$ FDIHC & $\Delta$ RDHHC & & \\
\hline & $\Delta \mathrm{GDP}$ & & $12.642 * * *$ & 5.427 & & & $0.678^{* * *}$ & $\mathrm{FDI} \geq \mathrm{GDP} ; \mathrm{RD} \neq>\mathrm{GDP}$ \\
\hline \multirow[t]{3}{*}{ Model 1} & $\Delta \mathrm{FDI}$ & 3.819 & & 5.237 & & & 0.009 & $\mathrm{GDP} \neq>\mathrm{FDI} ; \mathrm{RD} \neq>\mathrm{FDI}$ \\
\hline & $\Delta \mathrm{RD}$ & $13.967^{* * *}$ & $25.808^{* * *}$ & & & & $0.013^{* * *}$ & $\mathrm{GDP} \geq \mathrm{RD} ; \mathrm{FDI} \geq \mathrm{RD}$ \\
\hline & $\Delta \mathrm{GDP}$ & & & & $15.190^{* * *}$ & $19.914^{* * *}$ & $-0.193^{* * *}$ & FDIHC $\geq$ GDP;RDHHC $\geq$ GDP \\
\hline \multirow[t]{2}{*}{ Model 2} & $\triangle \mathrm{FDIHC}$ & $65.001 * * *$ & & & & $15.211^{* * *}$ & $24.520 * *$ & GDP $\geq$ FDIHC;RDHHC $\geq$ FDIHC \\
\hline & $\triangle \mathrm{RDHHC}$ & $10.887 * *$ & & & $39.629 * * *$ & & $0.313^{* * *}$ & $\mathrm{GDP} \geq \mathrm{RDHHC} ; \mathrm{FDIHC} \geq \mathrm{RDHHC}$ \\
\hline
\end{tabular}

Note: Model 1: The VECM between GDP, FDU, and R\&D; Model 2: The VECM between GDP, FDIHC, and RDHHC; $\geq$ means that the left side can cause the right side; $\neq>$ means that the left side cannot cause the right side; ${ }^{* * *}, * *$, and * denote significance at the $1 \%, 5 \%$, and $10 \%$ levels, respectively.

According to these results, first, the long run balance relation can be observed through whether the error correction term estimation coefficient $(\varnothing)$ of the previous period $(\mathrm{t}-1)$ has a negative sign. The results of this estimation show that the effects of FDIHC and RDHHC on GDP are all statistically significant (FDIHC $\rightarrow$ GDP; RDHHC $\rightarrow$ GDP), which implies that FDIHC and RDHHC have mutually long run effects on GDP. However, there is no long run impact of RDHHC and GDP on FDIHC or of FDIHC and GDP on RDHHC. Second, in the short run Granger causal analysis, it is only necessary to test whether the coefficient of each differenced explanatory variable is statistically significant. According to the results of this estimation (based on the Wald test), FDIHC and RDHHC affect GDP in the short run (FDIHC $\rightarrow$ GDP; RDHHC $\rightarrow$ GDP), and FDIHC and RDHHC are mutually affected in the short run (FDIHC $\leftrightarrow$ RDHHC). In Model 1, there is no long run effect between GDP, FDI, and R\&D; in the short run, FDI affects GDP, and GDP and FDI affect R\&D (FDI $\leftrightarrow$ GDP; FDI $\rightarrow$ R\&D). Comparing Model 1 and Model 2 shows that FDI has a significant impact on GDP growth in the long run when interacted with human capital. This result suggests that a country's continuous development requires the input of human capital along with various development factors. This result also shows that an organic combination of human capital and a driving force for development, such as FDI or R\&D, is important in the short run.

In addition, I conduct the variables decomposition test and present the result in Table 7 . This result can bolster the Granger causality finding explained above. The variance decomposition of the prediction error is a methodology for measuring the relative importance of each variable in the model. First, in Model 1, GDP is explained by the impact of GDP in the short run, and, in the long run, the explanatory power of R\&D increases to more than $20 \%$. For FDI, the explanatory power increases to $12 \%$ in the long run, but in the medium term, the explanatory power decreases to $4 \%$, which indicates a relatively dynamic change overall; in the short run, FDI has a self-explanatory power of $42 \%$, but in the long run, its own driving force for growth falls to $3.8 \%$. For R\&D, the explanatory power of GDP and R\&D gradually decline over time; the explanatory power of FDI relative to R\&D gradually increases to $13 \%$.Applying the variance decomposition method to model 2 establishes that almost $100 \%$ of GDP is explained by shocks to GDP in the short run. In the long run, FDIHC and RDHHC account for economic growth of $8 \%$ and $56 \%$, respectively (see Table 6, model 2). Furthermore, FDIHC is hardly affected by other variables (GDP and RDHHC) in the short run. However, in the long run, the explanatory power of FDIHC is reduced to $34 \%$, and the RDHHC has more than $50 \%$ explanatory power. Finally, RDHHC shows a self-explanatory power of 50\% in both the short and long run. FDIHC shows strong explanatory power over time, but GDP shows weak explanatory power over time. Taken together, the human resources in the R\&D sector have a significant impact on GDP, FDI, and R\&D itself in the long run. This finding implies that R\&D input requires investment in software, as well as hardware, and that there is a need for uncompromising investment in professional researchers and advanced talent. 
Table 7. Results of the variance decomposition test.

\begin{tabular}{|c|c|c|c|c|c|c|c|c|c|c|}
\hline \multirow[b]{2}{*}{ Model 1} & \multirow[b]{2}{*}{ Period } & \multicolumn{3}{|c|}{ Variance Decomposition of GDP: } & \multicolumn{3}{|c|}{ Variance Decomposition of FDI: } & \multicolumn{3}{|c|}{ Variance Decomposition of RD: } \\
\hline & & GDP & FDI & RD & GDP & FDI & RD & GDP & FDI & RD \\
\hline & 1 & 100.000 & 0.000 & 0.000 & 57.744 & 42.256 & 0.000 & 5.196 & 3.011 & 91.793 \\
\hline & 2 & 87.815 & 11.426 & 0.758 & 73.113 & 23.863 & 3.023 & 53.172 & 1.406 & 45.422 \\
\hline & 3 & 86.537 & 11.483 & 1.981 & 78.482 & 17.939 & 3.579 & 82.324 & 2.519 & 15.157 \\
\hline & 4 & 86.436 & 5.584 & 7.981 & 77.944 & 12.140 & 9.916 & 92.215 & 1.413 & 6.372 \\
\hline & 5 & 82.320 & 3.901 & 13.779 & 78.786 & 8.200 & 13.015 & 89.006 & 1.497 & 9.497 \\
\hline & 6 & 75.875 & 5.446 & 18.678 & 76.722 & 6.498 & 16.780 & 82.146 & 2.409 & 15.445 \\
\hline & 7 & 70.521 & 7.914 & 21.565 & 75.955 & 5.551 & 18.495 & 74.512 & 5.309 & 20.179 \\
\hline & 8 & 67.682 & 9.978 & 22.340 & 76.522 & 4.701 & 18.777 & 68.985 & 8.804 & 22.210 \\
\hline & 9 & 66.266 & 11.826 & 21.908 & 77.296 & 4.364 & 18.340 & 65.945 & 11.695 & 22.360 \\
\hline & 10 & 66.649 & 12.225 & 21.126 & 78.568 & 3.886 & 17.545 & 65.453 & 13.196 & 21.351 \\
\hline \multirow{12}{*}{ Model 2} & \multirow[b]{2}{*}{ Period } & \multicolumn{3}{|c|}{ Variance Decomposition of GDP: } & \multicolumn{3}{|c|}{ Variance Decomposition of FDIHC: } & \multicolumn{3}{|c|}{ Variance Decomposition of RDHHC: } \\
\hline & & GDP & $\begin{array}{l}\text { FDI } \\
\text { HC }\end{array}$ & $\begin{array}{l}\text { RD } \\
\text { HHC }\end{array}$ & GDP & $\begin{array}{l}\text { FDI } \\
\text { HC }\end{array}$ & $\begin{array}{l}\text { RD } \\
\text { HHC }\end{array}$ & GDP & $\begin{array}{l}\text { FDI } \\
\text { HC }\end{array}$ & $\begin{array}{l}\text { RD } \\
\text { HHC }\end{array}$ \\
\hline & 1 & 100.000 & 0.000 & 0.000 & 0.111 & 99.889 & 0.000 & 34.961 & 9.886 & 55.153 \\
\hline & 2 & 92.431 & 0.085 & 7.484 & 0.666 & 93.845 & 5.489 & 46.818 & 15.786 & 37.396 \\
\hline & 3 & 86.651 & 0.482 & 12.867 & 9.036 & 82.328 & 8.636 & 37.850 & 16.274 & 45.877 \\
\hline & 4 & 73.417 & 0.585 & 25.998 & 8.375 & 79.250 & 12.375 & 31.800 & 19.019 & 49.181 \\
\hline & 5 & 59.944 & 1.600 & 38.456 & 19.070 & 51.688 & 29.242 & 26.535 & 19.421 & 54.043 \\
\hline & 6 & 54.724 & 2.382 & 42.894 & 23.455 & 37.442 & 39.102 & 29.518 & 15.838 & 54.644 \\
\hline & 7 & 49.747 & 3.805 & 46.447 & 20.199 & 37.253 & 42.548 & 31.541 & 14.153 & 54.306 \\
\hline & 8 & 42.652 & 5.810 & 51.538 & 16.087 & 38.751 & 45.162 & 28.512 & 16.374 & 55.114 \\
\hline & 9 & 37.212 & 7.356 & 55.432 & 13.162 & 38.459 & 48.379 & 25.815 & 19.219 & 54.966 \\
\hline & 10 & 35.352 & 7.983 & 56.666 & 14.171 & 34.651 & 51.179 & 23.886 & 21.135 & 54.979 \\
\hline
\end{tabular}

\section{Discussion}

According to the development paths that many countries have followed, growth factors can be divided into material and human resource development, both of which impact sustainability. Material resources can be further divided into domestic and foreign capital, and human resources can be divided into simple labor and high-quality human capital. In general, in the early stage of national development, simple labor and foreign capital become the main driving force for development; however, domestic capital and high-quality human capital are important for the country to develop at a certain level and to continue to develop.

Since the Chinese economic reforms of 1978 (or "reform and opening-up"), the country has mobilized enormous human and material resources to lead development. Until 1990, labor-intensive industries, combined with foreign capital and cheap labor, led to a boom in the economy. After 1990, domestic and foreign capital in the market, along with simple and high-level labor forces, were used to further lead economic growth. Currently, China has been following a low growth trend with the New Normal. It has so far established a socialist market economic system, characterized by Chinese traits, in order to achieve a sustainable society.

In particular, industrial restructuring, the training of start-up talent, and global infrastructure projects have been driving forces for Chinese growth. However, a wide range of growth concerns has also arisen. Despite these concerns, the country has continued to find drivers for sustainable growth, pursuing economic growth in line with its methods. Hence, our interest lies in the human capital enhancement policy that China has pursued steadily since its "reform and opening-up." FDI and R\&D can combine with high-quality human capital to maximize investment performance, which can be explained by the fact that China has been able to record GDP growth of close to 10\% since the 1990s. In the future, its power to pursue stable and sustainable growth is "people"; hence, I analyze economic growth through the interaction between material resources (FDI and R\&D) and human capital using a two-step approach (SNA and VECM).

This study has several implications. First, FDI and R\&D, which have maintained growth in China, have formed many networks related to human capital. This finding, again, serves as a reminder to not overlook human capital factors in analyzing the impacts of FDI and R\&D on economic growth in general. Particularly, in countries that are in the process of transition from state-led development to private-led development, such as China, the importance of human capital has been increasing [73]. 
This means that there is an increase in opportunities that could stimulate domestic education, an inflow of more high-quality human capital to the market, and the efficient utilization of labor resources. In particular, given the keywords of economic growth in China-namely, the transition to economic and sustainable development-the role of advanced talent in R\&D becomes even more important. From the perspective of absorption capacity, our results support the notion that, no matter the quality of the FDI and R\&D activities undertaken, if human capital has not been formed to accept them, then the two main factors for economic growth are limited [37]. Therefore, given the network analysis results, China should continue to pursue FDI and R\&D input policies but must pursue efficiency and efficiency maximization strategies combined with human capital.

Second, according to the results of the VECM analysis, China's reforms after the 1990s have been relatively successful [74]. The technology and management know-how of multinational corporations in China have been sufficiently transferred, and human capital that can utilize them has been developing in line with FDI inflows. In particular, China, which is accustomed to accepting foreign culture, seems to have rapidly absorbed the cultures of foreign companies in order to generate sufficient synergy with domestic human capital and foreign companies. This process is desirable not only for emphasizing quantitative aspects in the process of attracting FDI but also for considering qualitative aspects, such as the transfer of advanced technology and advanced management techniques. In addition, cultivating qualitative talent through education at a global level, beyond the development of quantitative human resources, will enable the synergetic effects of human capital with foreign companies in China. In other words, there should be a qualitative improvement at the level of global education that can be easily applied and adapted to the culture and ability of the enterprise that foreign companies demand.

In terms of $R \& D$, it is also necessary to give sufficient consideration (salary and welfare) to Chinese advanced manpower, which has been improving steadily. We must establish a policy to maximize the efficiency and effectiveness of R\&D inputs. In particular, in order to obtain good results in terms of their attributes, $R \& D$ inputs should be promoted from mid- and long-term perspectives rather than from a short-term perspective. Currently, it is crucial to support high-level personnel who are patient and work within the R\&D field. Nevertheless, China has a variety of policies created to attract talented overseas human resources and to cultivate high-quality human resources. However, considering the current economic situation, which is still highly likely to develop, it is necessary to foster more advanced human resources within China and to attract foreign talent to enhance the effectiveness of R\&D investment utilization.

\section{Conclusions}

This study investigated the influence of the driving forces of the national economy-FDI and R\&D—on GDP growth when interaction variables with human capital were also included. Based on the literature on endogenous economic development, this study identified FDI and R\&D, which affect national development, as key variables; it then examined the effect of the interaction with human capital on GDP as a factor for sustained economic growth.

First, I looked at the extent to which human capital-related words are connected through data mining — with FDI and R\&D as keywords—and identified the clusters of words related to FDI, R\&D, and human capital through network analysis. This analysis confirmed that the roles and importance of human capital in FDI and R\&D input are strongly connected. In other words, in studying the effects of FDI and R\&D on sustainable economic development, I found that interaction variables combined with human capital should be applied over a single variable.

Second, based on the results of network analysis, VECM was implemented by interacting the FDI and R\&D variables with human capital, and the results were compared to those of the model with the missing human capital factor (GDP-FDI-R\&D). The FDI-human capital and R\&D-human capital interactions showed positive (+) influences on GDP growth both in the short and long run. In particular, the R\&D-human capital interaction was shown to have a significant impact on GDP growth compared to the FDI-human capital interaction. This finding leads us to conclude that it is 
necessary to nurture high-quality human resources for continuous national development and create an environment in which they can engage in work and achieve results. In addition, the FDI- and R\&D-human capital interactions are mutually influential, which can be seen as a complementary relationship between FDI, R\&D, and human capital, leading to national development.

Based on these results, academic implications can also be drawn. First, when discussing national development, it is necessary to consider human capital, as well as FDI and R\&D, and, especially, the influence of the interaction between these variables on national growth. Second, in the study of national economic growth, the robustness of the variables used in the research model should be improved upon by using unstructured data. Attempts must be made to identify the various meanings of unstructured data and to find words and variables that could be meaningfully applied to future research. Third, it is important to continue to expand FDI and R\&D in order to overcome low growth and improve sustainable economic growth. However, it is necessary to educate and attract talent to maximize the efficiency of the inputs. It is also necessary to invest capital in accordance with national characteristics and development goals in detail and, at the same time, to cultivate human resources to maximize investment performance.

Despite the aforementioned meaningful results, this study has certain limitations. First, I did not consider the spillover, dynamic, and crowding out effects among variables, because the statistical data available in each region in China are still very limited. Future research and policy implications can be derived if these data are systematically constructed. Second, I also did not consider the qualitative aspects of human capital in the process of selecting interaction variables. In addition to FDI, R\&D, and human capital, there are factors that influence national development, but they are not considered comprehensive. This raises the need to consider interactions with new variables, such as ICT technological aspects, information and communication infrastructure, and national maturity, while taking into account the increasing complexity of development factors.

Funding: This research received no external funding.

Conflicts of Interest: The authors declare no conflict of interest.

\section{Appendix A}

The text mining technique used in this study utilizes the TF-IDF value, which measures the importance of words in a document, and the degree centrality value, which measures the connection centrality of words in the document. In using the TF-IDF value, this study applies a typical measurement formula (see Equation (A1)) [57]:

$$
\mathrm{TF}-\mathrm{IDF}=\mathrm{TF} \times \mathrm{IDF}=t f_{x, y} \times \log \left(\frac{N}{d f_{x}}\right)
$$

in which $t f_{x, y}$ denotes the frequency of $x$ in $y, d f_{x}$ denotes the number of documents containing $x$, and $N$ indicates the total number of documents.

In terms of degree centrality, for the non-directional/binary graph including $g$ nodes, the degree centrality of node $i$ is obtained by summing the number of connections that node $i$ makes with the remaining $(n-1)$ other nodes (see Equation (A2)) [75]:

$$
C_{D}\left(N_{i}\right)=\sum_{j=1}^{g} x_{i j}, i \neq j
$$

in which $C_{D}\left(N_{i}\right)$ denotes the degree centrality of node $i, g$ is the number of nodes, and $\sum_{j=1}^{g} x_{i j}$ indicates the number of connections that node $i$ has with the $(g-\mathbf{1})$ other nodes. Degree centrality according to Equation (A2) is influenced by the size of the network. Therefore, it is necessary to eliminate the 
influence of the network size on degree centrality in order to compare the nodes. Considering the network size, the standardized formula is as follows (see Equation (A3)):

$$
C_{D}^{\prime}\left(N_{i}\right)=\frac{C_{D}\left(N_{i}\right)}{g-1}
$$

in which $C_{D}^{\prime}\left(N_{i}\right), C_{D}\left(N_{i}\right)$, and $g$ denote the standardized degree centrality of node $i$, the degree centrality of node $i$, and the number of nodes, respectively.

Table A1. The results of the relative term frequency and centrality for FDI.

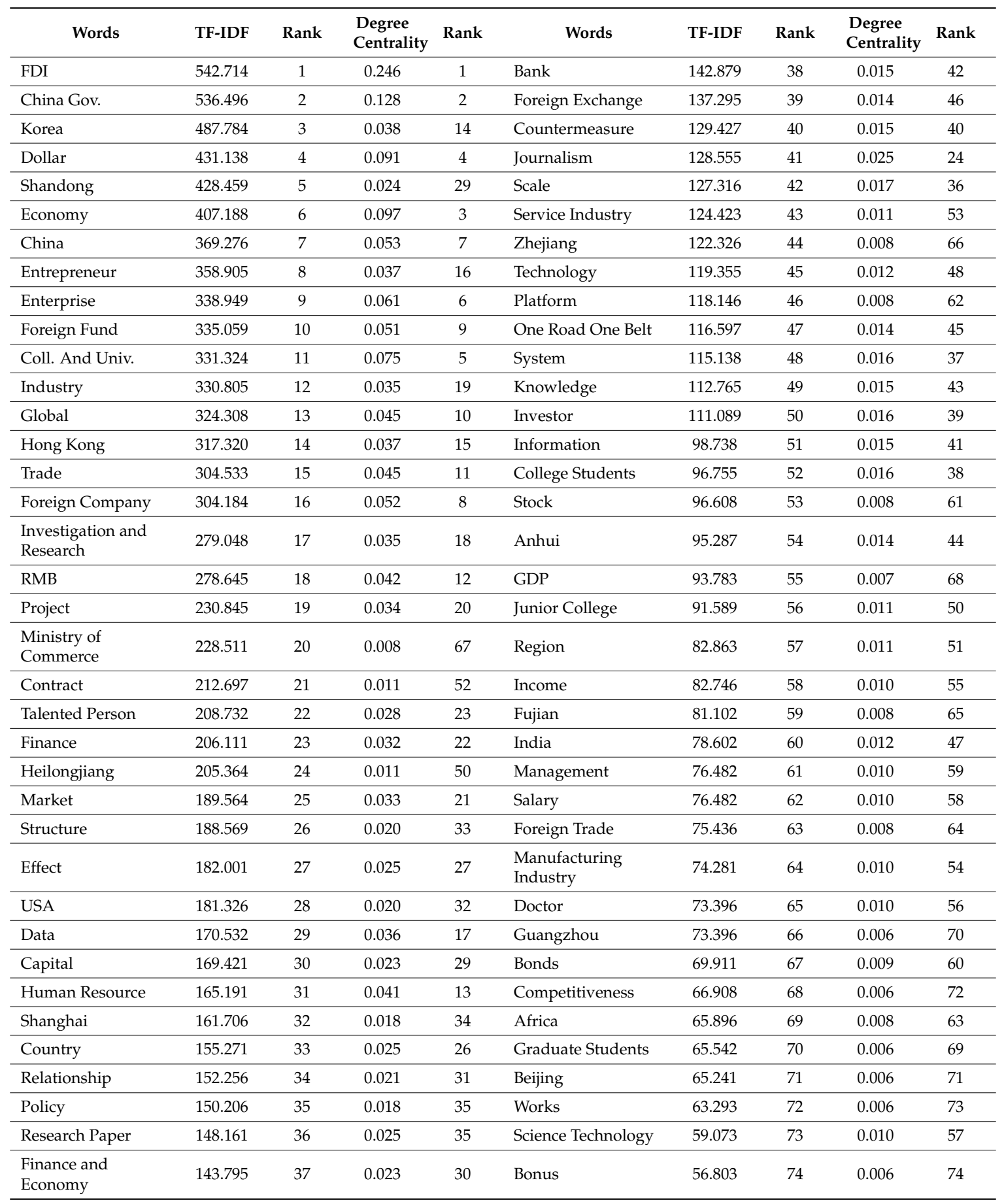


Table A2. The results of the relative term frequency and centrality for R\&D.

\begin{tabular}{|c|c|c|c|c|c|c|c|c|c|}
\hline Words & TF-IDF & Rank & Degree Centrality & Rank & Words & TF-IDF & Rank & Degree Centrality & Rank \\
\hline System & 587.789 & 1 & 0.122 & 1 & Contents & 156.080 & 42 & 0.025 & 17 \\
\hline Technology & 554.518 & 2 & 0.105 & 2 & Activity & 147.661 & 43 & 0.018 & 33 \\
\hline Project & 482.430 & 3 & 0.051 & 4 & $\begin{array}{l}\text { Talented } \\
\text { Person }\end{array}$ & 147.661 & 44 & 0.017 & 36 \\
\hline Enterprise & 424.206 & 4 & 0.059 & 3 & China & 144.794 & 45 & 0.020 & 27 \\
\hline New Drug & 362.651 & 5 & 0.034 & 10 & $\begin{array}{l}\text { Arts and } \\
\text { Crafts }\end{array}$ & 144.437 & 46 & 0.018 & 34 \\
\hline Information & 323.184 & 6 & 0.046 & 8 & Solution & 140.098 & 47 & 0.012 & 57 \\
\hline $\begin{array}{l}\text { Research } \\
\text { Paper }\end{array}$ & 301.616 & 7 & 0.051 & 5 & $\begin{array}{l}\text { Wisdom } \\
\text { Knowledge }\end{array}$ & 140.015 & 48 & 0.002 & 82 \\
\hline Document & 300.674 & 8 & 0.023 & 21 & Strategy & 137.831 & 49 & 0.012 & 58 \\
\hline Plan & 291.122 & 9 & 0.019 & 29 & Center & 130.492 & 50 & 0.016 & 41 \\
\hline $\begin{array}{l}\text { Science and } \\
\text { Technology }\end{array}$ & 285.639 & 10 & 0.046 & 7 & On-line & 128.555 & 51 & 0.014 & 49 \\
\hline Account & 282.847 & 11 & 0.023 & 22 & $\begin{array}{l}\text { Material } \\
\text { Science }\end{array}$ & 126.404 & 52 & 0.012 & 61 \\
\hline Medicine & 268.921 & 12 & 0.028 & 14 & Science & 123.944 & 53 & 0.014 & 47 \\
\hline China & 262.495 & 13 & 0.048 & 6 & Machine & 123.794 & 54 & 0.007 & 78 \\
\hline Cost & 244.710 & 14 & 0.027 & 16 & Funds & 122.326 & 55 & 0.008 & 77 \\
\hline Keynote & 243.562 & 15 & 0.013 & 51 & Global & 120.646 & 56 & 0.009 & 73 \\
\hline Product & 241.485 & 16 & 0.024 & 20 & Industry & 119.160 & 57 & 0.014 & 48 \\
\hline Platform & 240.823 & 17 & 0.031 & 11 & Computer & 118.044 & 58 & 0.013 & 52 \\
\hline Mode & 231.099 & 18 & 0.018 & 35 & Expert & 116.755 & 59 & 0.008 & 75 \\
\hline Expenditure & 230.836 & 19 & 0.015 & 46 & Feasibility & 116.210 & 60 & 0.004 & 80 \\
\hline University & 228.511 & 20 & 0.040 & 9 & College & 110.904 & 61 & 0.016 & 38 \\
\hline Automobile & 227.051 & 21 & 0.024 & 18 & Energy & 110.635 & 62 & 0.011 & 68 \\
\hline $\begin{array}{l}\text { Traditional } \\
\text { Chinese } \\
\text { Medicine }\end{array}$ & 224.117 & 22 & 0.020 & 26 & Shanghai & 110.635 & 63 & 0.011 & 67 \\
\hline Capital & 219.775 & 23 & 0.017 & 37 & $\begin{array}{l}\text { Human } \\
\text { Resource }\end{array}$ & 109.888 & 64 & 0.013 & 50 \\
\hline Presentation & 205.260 & 24 & 0.019 & 31 & Knowledge & 109.741 & 65 & 0.012 & 55 \\
\hline Resources & 203.983 & 25 & 0.029 & 12 & Agriculture & 107.602 & 66 & 0.011 & 66 \\
\hline $\begin{array}{l}\text { Academic } \\
\text { Degree }\end{array}$ & 199.626 & 26 & 0.013 & 53 & Economy & 107.438 & 67 & 0.019 & 30 \\
\hline Data & 198.793 & 27 & 0.021 & 25 & Mechanics & 107.202 & 68 & 0.012 & 54 \\
\hline Works & 194.081 & 28 & 0.028 & 13 & Institution & 105.079 & 69 & 0.012 & 60 \\
\hline Professional & 193.823 & 29 & 0.019 & 28 & Important & 103.972 & 70 & 0.010 & 71 \\
\hline Intelligence & 187.768 & 30 & 0.019 & 32 & Foundation & 103.020 & 71 & 0.016 & 39 \\
\hline Engineer & 186.855 & 31 & 0.028 & 15 & Anhui & 101.938 & 72 & 0.008 & 74 \\
\hline Master & 184.159 & 32 & 0.010 & 69 & Preparation & 101.938 & 73 & 0.007 & 79 \\
\hline Method & 179.280 & 33 & 0.024 & 19 & $\begin{array}{l}\text { Scientific } \\
\text { Research }\end{array}$ & 101.938 & 74 & 0.011 & 64 \\
\hline Software & 179.280 & 34 & 0.021 & 24 & Wuhan & 101.268 & 75 & 0.010 & 70 \\
\hline Biology & 179.195 & 35 & 0.022 & 23 & Structure & 94.830 & 76 & 0.011 & 62 \\
\hline Equipment & 169.713 & 36 & 0.015 & 43 & Utility & 94.605 & 77 & 0.011 & 65 \\
\hline Teaching & 165.952 & 37 & 0.011 & 63 & Channel & 93.575 & 78 & 0.004 & 81 \\
\hline Curriculum & 160.803 & 38 & 0.012 & 59 & Teacher & 90.273 & 79 & 0.015 & 44 \\
\hline Electronics & 159.424 & 39 & 0.016 & 40 & Environment & 89.704 & 80 & 0.009 & 72 \\
\hline Network & 158.686 & 40 & 0.015 & 45 & $\begin{array}{l}\text { Research } \\
\text { Center }\end{array}$ & 88.533 & 81 & 0.012 & 56 \\
\hline Food & 156.286 & 41 & 0.015 & 42 & Academic & 87.036 & 82 & 0.008 & 76 \\
\hline
\end{tabular}




\section{Appendix B}

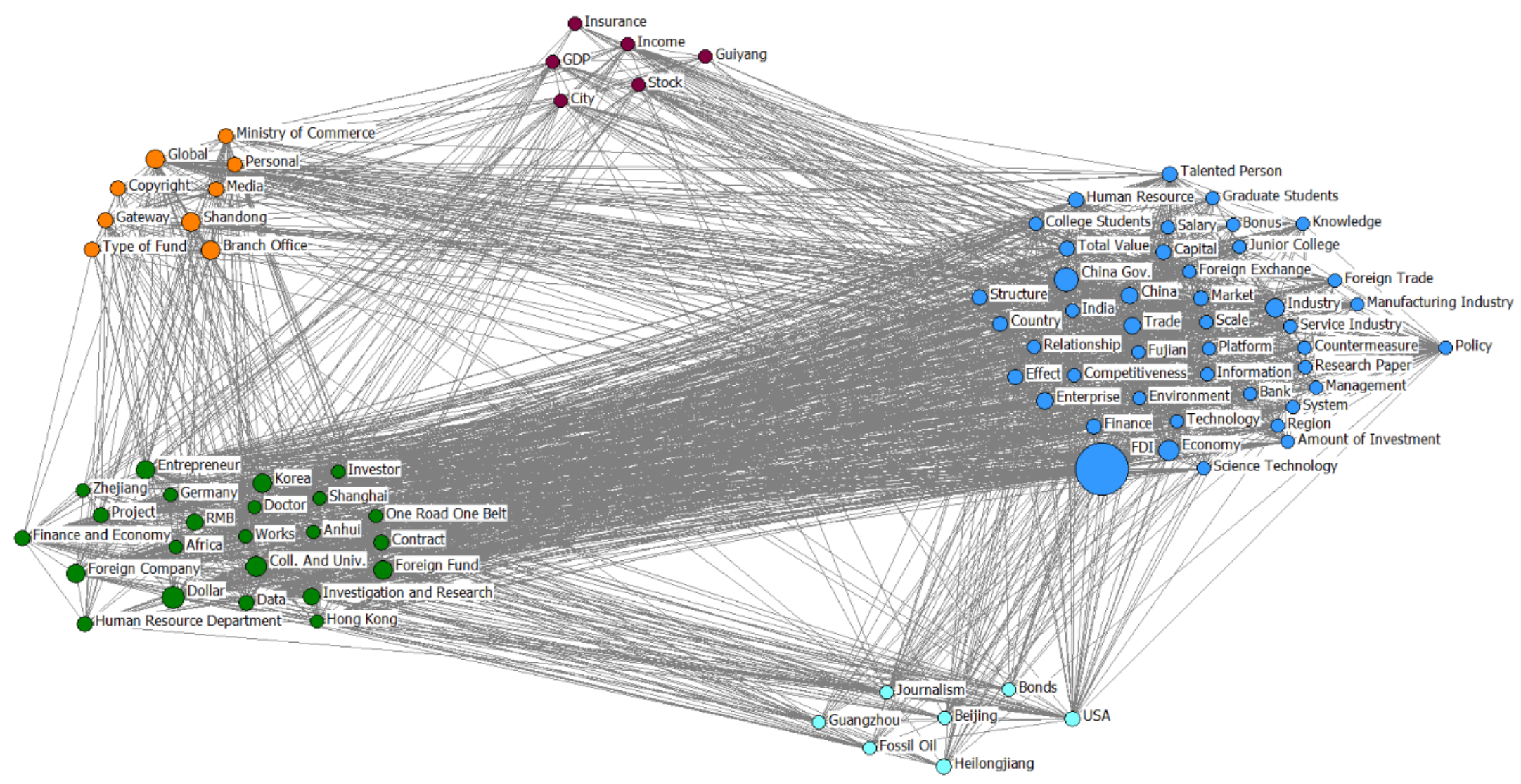

Figure A1. The result of semantic network analysis for FDI. 


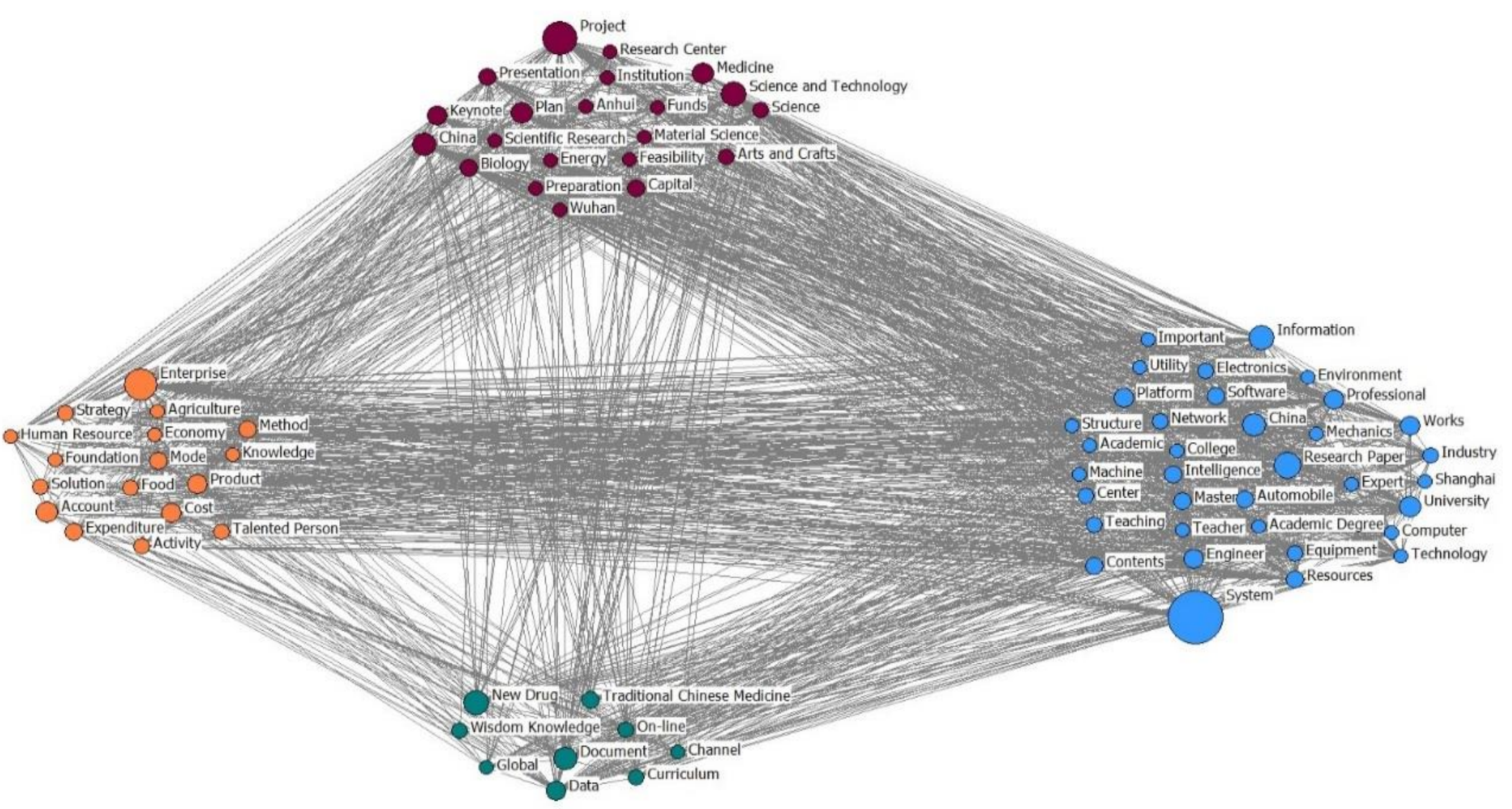

Figure A2. The result of semantic network analysis for R\&D. 


\section{References}

1. Zhu, L.; Jeon, B.N. International R\&D spillover: Trade, FDI, and information technology as spillover channels. Rew. Int. Econ. 2007, 15, 955-976.

2. Jing, C.; Song, Y.H. FDI in China: Institutional evolution and its impact on different sources. In Proceedings of the 15th Annual Conference of the Association for Chinese Economics Studies Australia (ACESA), Melbourne, Australia, 2-3 October 2003. Available online: http://mams.rmit.edu.au/185g10z02ukp.pdf (accessed on 18 January 2018).

3. Caves, R. Multinational Enterprise and Economic Analysis, 2nd ed.; Cambridge University Press: Cambridge, UK, 1996.

4. Dunning, J.; Lundan, S. Multinational enterprises and the global economy. Trans. Corp. 2010, 19, $103-106$. [CrossRef]

5. Bravo-Ortega, C.; Marin, A.G. R\&D and productivity: A two-way avenue? World Dev. 2011, 39, $1090-1107$.

6. Cameron, G.; Proudman, J.; Redding, S. Technological convergence, R\&D, trade and productivity growth. Eur. Econ. Rev. 2005, 49, 775-807.

7. Coe, D.T.; Helpman, E.; Hoffmaister, A.W. International R\&D spillovers and institutions. Eur. Econ. Rev. 2009, 53, 723-741.

8. Kafouros, M.I. R\&D and productivity growth: Evidence from the UK. Econ. Innov. New Technol. 2005, 14, 479-497.

9. O’Mahony, M.; Vecchi, M. R\&D, knowledge spillovers and company productivity performance. Res. Policy 2009, 38, 35-44.

10. Borensztein, E.; Gregorio, J.D.; Lee, J.W. How does foreign direct investment affect economic growth? J. Int. Econ. 1998, 45, 115-135. [CrossRef]

11. $\mathrm{Xu}, \mathrm{G}$.; Wang, R. The effect of foreign direct investment on domestic capital formation, trade and economic growth in a transition economy: Evidence from China. Glob. Econ. J. 2007, 7, 1524-5861.

12. Zhang, Q.; Felmingham, B. The role of FDI, exports and spillover effects in the regional development of China. J. Dev. Stud. 2002, 38, 157-178. [CrossRef]

13. Chen, C.L. Do inland provinces benefit from coastal foreign direct investment in China? China World Econ. 2015, 23, 22-41. [CrossRef]

14. Jeon, Y.; Park, B.I.; Ghauri, P.N. Foreign direct investment spillover effects in China: Are they different across industries with different technological levels? China Econ. Rev. 2013, 26, 105-117. [CrossRef]

15. Ha, Y.J.; Giroud, A. R\&D spillovers from foreign direct investment (FDI): The role of firm-level heterogeneity. In Proceedings of the 36th EIBA Annual Conference, Porto, Portugal, 9-11 December 2010.

16. Hsu, P.H.; Tian, X.; Xu, Y. Financial development and innovation: Crosscountry evidence. J. Financ. Econ. 2014, 112, 116-135. [CrossRef]

17. Paunov, C. The global crisis and firm's investment in innovation. Res. Policy 2012, 41, 24-35. [CrossRef]

18. Tongue, N.; Allan, R. Growth, R\&D intensity and commercial lender relationships. J. Small Bus. Entrep. 2013, $26,109-124$.

19. Choi, S.B.; Williams, C. The impact of innovation intensity, scope, and spillovers on sales growth in Chinese firms. Asia Pac. J. Manag. 2014, 31, 25-46. [CrossRef]

20. Lamperti, F.; Mavilia, R.; Castellini, S. The role of science parks: A puzzle of growth, innovation and R\&D investments. J. Technol. Transf. 2017, 42, 158-183.

21. Zhang, C.; Guo, B.; Wang, J. The different impacts of home countries characteristics in FDI on Chinese spillover effects: Based on one-stage SFA. Econ. Model. 2014, 38, 572-580. [CrossRef]

22. Romer, P. Endogenous technological change. J. Polit. Econ. 1990, 98, 71-102. [CrossRef]

23. Lucas, R.E., Jr. On the mechanics of economic development. J. Monet. Econ. 1988, 22, 3-42. [CrossRef]

24. Beugelsdijk, S.R.S.; Zwinkels, R. The impact of horizontal and vertical FDI on host country economic growth. Int. Bus. Rev. 2008, 17, 452-472. [CrossRef]

25. Baharumshah, A.Z.; Thanoon, M.A.-M. Foreign capital flows and economic growth in East Asian countries. China Econ. Rev. 2006, 17, 70-83. [CrossRef]

26. Bwayla, S.M. Foreign direct investment and technology spillovers: Evidence from panel data analysis of manufacturing firms in Zambia. J. Dev. Econ. 2006, 81, 514-526. [CrossRef] 
27. Javorcik, B.S. Does foreign direct investment increase the productivity of domestic firms? In search of spillovers through backward linkages. Am. Econ. Rev. 2004, 94, 605-627. [CrossRef]

28. Agosin, M.R.; Machado, R. Foreign investment in development countries: Does it crowd in domestic investment? Oxf. Dev. Stud. 2007, 33, 149-163. [CrossRef]

29. Fry, M.J. Foreign Direct Investment in a Macroeconomic Framework: Finance, Efficiency, Incentives, and Distortions; Policy Research Working Paper Series 1141; The World Bank: Washington, DC, USA, 1993; Available online: https:/ /ideas.repec.org/p/wbk/wbrwps/1141.html (accessed on 12 January 2018).

30. De Mello, L. Foreign direct investment-led growth: Evidence from time series and panel data. Oxf. Econ. Pap. 1999, 51, 133-151. [CrossRef]

31. Mencinger, J. Does foreign direct investment always enhance economic growth? Kyklos 2003, 56, 491-508. [CrossRef]

32. Ashraf, A.; Herzer, D.; Nunnenkamp, P. The effects of greenfield FDI and cross-border M\&As on total factor productivity. World Econ. 2016, 39, 1728-1755.

33. Carbonell, J.B.; Werner, R.A. Does foreign direct investment generate economic growth? A new empirical approach applied to Spain. Econ. Geogr. 2018, 1-32. [CrossRef]

34. Lipsey, R.E. Inward FDI and economic growth in development countries. Trans. Corp. 2000, 9, 67-95.

35. Zhang, K.H. Does foreign direct investment promote economic growth? Evidence from East Asia and Latin America. Contemp. Econ. Policy 2001, 19, 175-185. [CrossRef]

36. Durham, J.B.J. Absorptive capacity and the effects of foreign direct investment and equity foreign Portfolio investment on economic growth. Eur. Econ. Rev. 2004, 48, 285-306. [CrossRef]

37. Li, X.; Liu, X. Foreign direct investment and economic growth: An increasingly endogenous relationship. World Dev. 2005, 33, 393-407. [CrossRef]

38. Coe, D.T.; Helpman, E. International R\&D spillovers. Eur. Econ. Rev. 1995, 39, 137-147.

39. Goel, R.K.; Ram, R. Research and development expenditures and economic growth: A cross-country study. Econ. Dev. Cult. Chang. 1994, 42, 403-411. [CrossRef]

40. Griffith, R.; Redding, S.; Reenen, J.V. Mapping the two faces of R\&D: Productivity growth in a panel of OECD industries. Rev. Econ. Stat. 2004, 86, 883-895.

41. Guellec, D.; Potterie, B.P. R\&D and productivity growth: Panel data analysis of 16 OECD countries. Econ. Stud. 2001, 33, 103-126.

42. Lichtenberg, F.R. RED Investment and International Productivity Differences; NBER Working Paper No. 4161; National Bureau of Economic Research: Cambridge, MA, USA, 1992; Available online: http: / /www.nber. org/papers/w4161 (accessed on 10 December 2017).

43. Lichtenberg, F.R.; Potterie, B.P. International R\&D spillovers: A comment. Eur. Econ. Rev. 1998, 42, $1483-1491$.

44. Estrada, A.; Montero, J.M. R\&D Investment and Endogenous Growth: A SVAR Approach. 2009. Available online: https:/ / papers.ssrn.com/sol3/papers.cfm?abstractid=1494899 (accessed on 12 December 2017).

45. Howitt, P.; Mayer-Foulkes, D. RED, Implementation and Stagnation: A Schumpeterian Theory of Convergence Clubs; NBER Working Paper No. 9104; National Bureau of Economic Research: Cambridge, MA, USA, 2002; Available online: http:/ / www.nber.org/papers/w9104 (accessed on 22 February 2018).

46. Dowrick, S.; Rogers, M. Classical and technological convergence: Beyond the Solow-Swan growth model. Oxf. Econ. Pap. 2002, 54, 369-385. [CrossRef]

47. Bronzini, R.R.; Piselli, P. Determinants of long-run regional productivity with geographical spillovers: The role of R\&D, human capital and public infrastructure. Reg. Sci. Urban Econ. 2009, 39, 187-199.

48. Teixeira, A.A.C.; Fortuna, N. Human capital, R\&D, trade, and long-run productivity: Testing the technological absorption hypothesis for the Portuguese economy, 1960-2001. Res. Policy 2010, 39, 335-350.

49. Bengoa, M.; Román, V.M.-S.; Pérez, P. Do R\&D activities matter for productivity? A regional spatial approach assessing the role of human and social capital. Econ. Model. 2017, 60, 448-461.

50. Lopez-Rodriguez, J.; Martinez-Lopez, D. Looking beyond the R\&D effects on innovation: The contribution of non-R\&D activities to total factor productivity growth in the EU. Struct. Chang. Econ. Dyn. 2017, 40, 37-45.

51. Chung, C.; Park, H.W. Textual analysis of a political message: The inaugural addresses of two Korean presidents. Soc. Sci. Inf. 2010, 49, 215-239. [CrossRef]

52. Yuan, E.J.; Feng, M.; Danowski, J.A. "Privacy" in semantic networks on Chinese social media: The case of Sina Weibo. J. Commun. 2013, 63, 1011-1031. [CrossRef] 
53. Danowski, J.A. Network analysis of message content. In Progress in Communication Sciences; Barnett, G., Richards, W., Eds.; Ablex: Norwood, NJ, USA, 1993.

54. Doerfel, M.L. What constitutes semantic network analysis? A comparison of research and methodologies. Connections 1998, 21, 16-26.

55. ICTCLAS. 2012. Available online: http://ictclas.org/ictclas_about.html (accessed on 17 September 2017).

56. Son, D. Social Network Analysis; Kyungmoon: Seoul, Korea, 2002.

57. Salton, G.; Buckley, C. Term-weighting approaches in automatic text retrieval. Inf. Process. Manag. 1988, 24, 193-206. [CrossRef]

58. Borgatti, S.P.; Everett, M.G.; Freeman, L.C. UCINET for Windows: Software for Social Network Analysis; Analytic Technologies: Harvard, MA, USA, 2002.

59. Erkan, G.; Radev, D.R. LexRank: Graph-based centrality as salience in text summarization. J. Artif. Intell. Res. 2004, 22, 457-479.

60. Zhang, H.; Fiszman, M.; Shin, D.; Miller, C.M.; Rosemblat, G.; Rindflesch, T.C. Degree centrality for semantic abstraction summarization of therapeutic studies. J. Biomed. Inf. 2011, 44, 830-838. [CrossRef] [PubMed]

61. Wasserman, S.; Faust, K. Social Network Analysis: Methods and Applications; Cambridge University Press: New York, NY, USA, 1994.

62. Cho, S.E.; Choi, M.; Park, H.W. Government-civic group conflicts and communication strategy: A text analysis of TV debates on Korea's import of U.S. beef. J. Contemp. East. Asia 2011, 11, 1-20. [CrossRef]

63. Sung, B.; Park, S.-D. Who drives the transition to a renewable energy economy: Multi actor perspective on social innovation. Sustainability 2018, 10, 448. [CrossRef]

64. Marques, A.C.; Fuinhas, J.A.; Menegaki, A.N. Interactions between electricity generation sources and economic activity in Greece: A VECM approach. Appl. Energy 2014, 132, 34-46. [CrossRef]

65. Guilkey, D.K.; Salemi, M.K. Small sample properties of the three test of causality for Granger causal ordering in a bivariate stochastic system. Rev. Econ. Stat. 1982, 64, 668-680. [CrossRef]

66. Geweke, J.; Messe, R.; Dent, W. Comparing alternative tests for causality in temporal systems: Analytic result and experimental evidence. J. Econ. 1983, 21, 161-194. [CrossRef]

67. Granger, C.W.J. Some recent development in a concept of causality. J. Econ. 1988, 39, 199-211. [CrossRef]

68. Dickey, D.A.; Fuller, W.A. Distribution of the estimators for autoregressive time series with a unit root. J. Am. Stat. Assoc. 1979, 74, 427-431.

69. Phillips, P.C.B. Understanding spurious regressions in econometrics. J. Econ. 1986, 33, 311-340. [CrossRef]

70. Schwartz, R. Estimating the dimension of a model. Ann. Stat. 1978, 6, 461-464. [CrossRef]

71. Johansen, S. Statistical analysis for cointegration vectors. J. Econ. Dyn. Control 1988, 12, 231-254. [CrossRef]

72. Seker, F.; Ertugrul, H.M.; Cetin, M. The impact of foreign direct investment on environmental quality: A bounds testing and causality analysis for Turkey. Renew. Sustain. Energy Rev. 2015, 52, 347-356. [CrossRef]

73. Mai, L. China: Investing in Human Capital; OECD Observer No 290-291; Organisation for Economic Co-operation and Development: Paris, France, 2012; Available online: http:/ / oecdobserver.org/news/ fullstory.php/aid/3781/China:_Investing_in_human_capital.html (accessed on 23 May 2018).

74. Kim, Y.C. Economic transition in China and Russia. Eur. Sci. J. 2015, 1, 355-366.

75. Freeman, L.C. Centrality in social networks: I. Conceptual classification. Soc. Netw. 1979, 1, $215-239$. [CrossRef]

(c) 2018 by the author. Licensee MDPI, Basel, Switzerland. This article is an open access article distributed under the terms and conditions of the Creative Commons Attribution (CC BY) license (http://creativecommons.org/licenses/by/4.0/). 